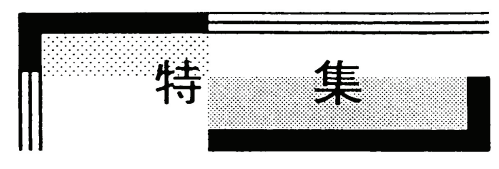

\title{
海域の土砂移動を知る* \\ Estimation of Coastal Sediment Transport
}

\author{
武 若 聡** \\ TAKEWAKA Satoshi
}

\begin{abstract}
Coastal erosion is a severe problem elsewhere along the Japanese island, and efforts have been paid to cope the situation. For sophisticated management of coastal erosion, we must understand the spatial and temporal distribution of sediment fluxes, however, this item is usually very difficult to observe directly. The alternative way to estimate this item is measurement of bottom topographies, and then assess the sediment flux indirectly using the continuity equation between temporal change of bottom elevation and divergence of sediment flux. In this article, estimation of coastal sediment transport in the field is discussed, and then an attempt to estimate the sediment motion at the river mouth is introduced.
\end{abstract}

Keywords: Coastal sediment, Sediment flux, Topography, Field measurement

\section{1. はじめに}

日本の海岸の多くは海岸侵食に悩まされてお り、関係者の尽力により、辛うじて現在の水際位 置 (汀線) を維持している海岸が多い。海岸侵食 に対応するには、海岸地形変動に関する理解と海 岸地形変動を制する技術が必要であり、これらに 関連する事象の分析、技術開発等は土木工学の一 つの分野である海岸工学で行われており、ここで は、波浪、流れ、漂砂、海岸構造物等が研究対象 である（例えば $[1,2] ） 。$

筆者は海岸地形変動に関する研究に興味を持 っており、その成果を海岸侵食対策に活用するこ とを目標としている。ここでは、先ず、海岸地形 の変動と土砂フラックスの関係、これらの観測方 法、海岸侵食対策について述心、続いて、河川か ら海岸に運ばれる土砂量を推定するための観測 事例を紹介する。最近になり、海岸地形を計測す る技術は急速に進展しているが、土砂フラックス を測定あるいは推定する技術に関する研究の余 地は未だ大きいと筆者は感じている。

\section{2. 海岸地形と土砂移動}

\section{1 海岸地形変動と土砂フラックスの関係}

海岸地形を知るとは、陸上から海中にかけての 地盤高 $h$ の時空間分布 $h(x, y, t)$ を知ることであ る。ここで $x, y$ は平面位置を表わ寸座標、 $t$ は時 間である。海岸地形は波が海岸に打ち寄せる際に、 また、潮汐・海流・海浜流等により時々刻々変化 しており、これを全て追跡することは困難である。 海岸侵食対策を考える上で重要となるのは、海 岸地形が大きく変動する台風、冬季の暴浪等の荒 天前後の変化 (短期間)、年間に生じる季節的な 変化 (中期間)、数年から数十年にわたる変化卜 レンド (長期間) である。これらを把握するため に、測量 (深浅測量、汀線測量) が行われており、 また、リモートセンシング手法により高頻度・高 密度に地形データを取得する研究も精力的に行 われている。

海岸地形の変動は土砂の移動、寸なわち、土砂 フラックスによりもたらされる。土砂フラックス は単位時間当たりに検査面を通過する土砂量 (体

* 2019.5.14 受付

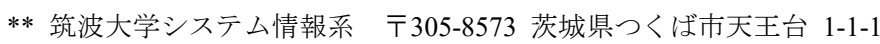

TEL: (029) 853-5361 E-mail: takewaka@kz.tsukuba.ac.jp 
積）である。 $x$ 方向、 $y$ 方向の土砂フラックス（単 位幅、単位時間当たり）を $Q_{x} 、 Q_{y}$ とすると、地盤 高の時間変化と土砂フラックスの収束・発散の間 には次の土砂の連続式が成立する。（例えば [3]）

$$
\frac{\partial h}{\partial t}+\frac{\partial Q_{x}}{\partial x}+\frac{\partial Q_{y}}{\partial y}=0
$$

土砂フラックス、すなわち土砂の移動は、波、 流れ（海流、潮流、海浜流）などによりもたらさ される。これらの外力が大きくなる荒天時に活発 になり、これに伴い地形の変動も大きくなる。

様々な外力と土砂フラックスの関連を調べる 解析的、実験、フィールド観測による研究は数多 く行われており、一定の成果は蓄積されている。 しかしながら、現象が相当に複雑なため、あらゆ る場面について土砂フラックス（向きと大きさ） を予測する方法は確立されておらず、いまだ経験 的な面が多く残されている。海域では、土砂はあ らゆる方向に移動できるので、移動方向の確実な 予測でさえ難しいのが現状である。（例えば [4]）

\section{2 土砂フラックスと海岸地形の観測}

土砂フラックスを直接計測するためには、局所
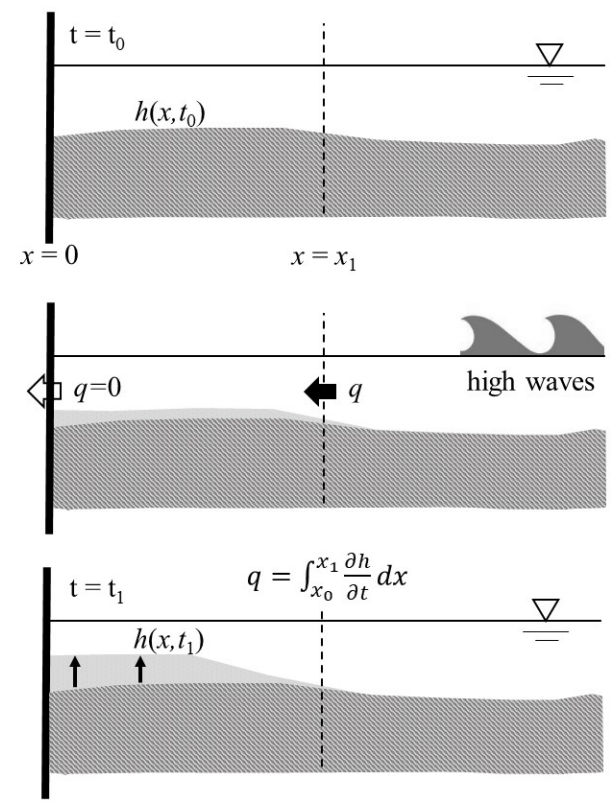

Fig. 1 Estimation of sediment flux from topography variation close to a rigid wall. Bottom configuration has been changed during high wave event, and sediment influx during this period can be computed from elevation change. $q$ is the averaged sediment flux during the event.
の土砂濃度 $c$ と流速 $u$ を計測し、これらの積 $c u$ を鉛直方向に積算しなければならない。これを精 密に行うのは実験室でさえ難しい。海域では、荒 天時に観測機器（流速計、圧力計、濃度計等）を 海中、海底に展開して事後にデータを回収するの は非常に困難である。観測機器を海底面に固定で きたとしても、土砂移動が活発になり地形変動が 生じて地盤面が低下寸ると機器が流失し、あるい は、逆に砂が設置位置に堆積すると埋没し、荒天 後に機器を回収できなくなることがしばしばあ る。

荒天時の土砂フラックスを推定するための次 善の策として行えるのは、海底地形の計測 (測量) である。地盤高のデータを豊富に入手できれば、 荒天前後の地盤高変化量を求め (式 (1) の左辺第 一項)、何らかの仮定をした上で土砂の連続式 (1) を時間方向、空間方向に積分し、荒天中の土砂フ ラックス (積算值) を推定することができる。例 えば、荒天前後の詳細な海底地形データが入手で き、また、防波堤等の土砂が通過できない不透過 境界を設定できる場合、この近傍の土砂フラック スの時間積算值を見積もることができる (Fig. 1)。

一方、海底地形のデータを豊富に収集できたと しても、土砂フラックスを推定できない場合があ る(Fig. 2)。土砂が移動した結果が地盤高の変化 として現れない場合、連続式 (1) を介して土砂フ ラックスを推定することはできない。

以上のように、海域の土砂フラックスを推定す ることは簡単でなく、現在でも様々なアイデアに よりこれを推定する研究が行われている。

\section{3 海岸侵食対策と土砂フラックスの推定}

砂浜海岸の多くは、河川より出水時に土砂が河

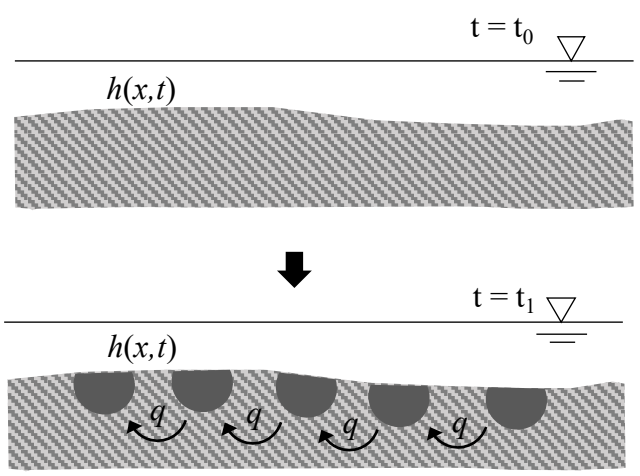

Fig. 2 Sediment flux without bottom variation. 

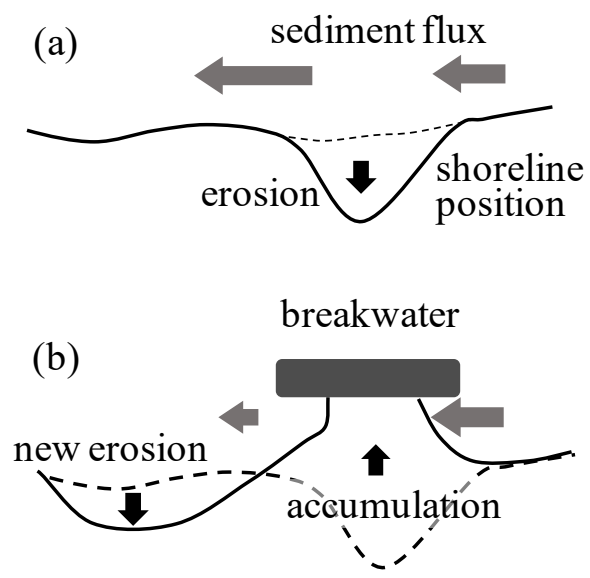

Fig. 3 Schematic explanation of coastal erosion propagation. (a) Erosion: shoreline retreats by imbalance of sediment flux. (b) Countermeasure: breakwater is set to keep sand at eroded area. Sand accumulates behind the breakwater, however, sediment flux is interrupted and new eroded area appears in the vicinity.

口域に供給され、これが波の作用により沿岸に運 ばれる、という一連のプロセスにより形成される と考える。この場合、砂浜にある砂は常に入れ替 わっており、海岸工学の分野ではこれを、土砂が 絶え間なく動き、海浜が動的に維持される「動的 平衡状態」と呼んでいる（Fig. 2 に説明したよう な状況）。ここで、河川からの土砂供給が減少す る (例えば、ダムの設置)、沿岸での土砂の動きが 妨げられる（例えば、港の建設）等の人為的な影 響があると、土砂の連続的な供給が遮断され海岸 侵食が生じる。海域では、土砂供給が絶たれても 引き続き波は作用するので、砂は局所的に失われ、 陸域と海域の境界である汀線位置が陸側に後退 する。

海岸侵食対策としては、長らく、局所的に土砂 を留めて汀線位置を維持する「ストック管理」に より砂浜を「静的平衡状態」に維持寸ることが行 われてきた。ところが、対策工（海岸構造物：護 岸、突堤、離岸堤など）が土砂移動の連続性をさ らに妨げ、侵食域が拡大寸る事例がしばしば見ら れる (Fig. 3)。構造物の背後には砂が堆積し、汀 線の位置を確保できるものの、土砂フラックスを 遮断するため隣接域に新たな侵食域が発生する。 フィールドでは、これは数年の時間ラグを経て顕 在化することが多い。
以上の反省として、流域における土砂移動（流 砂）と海域の土砂移動（漂砂）の連続性を確保し ながら、海岸に供給される土砂量を確保して侵食 対策を行うフラックス管理へのパラダイムシフ トが提唱され、関係者の間で共有されつつある。

フラックス管理の実現には、流域から海域への 土砂供給促進方法、土砂フラックスを制御可能な 構造物の開発、高精度・高分解能に土砂フラック スの時空間分布を観測する技術、観測結果の地形 予測モデルへの反映方法など、様々な要素技術が 必要であり、それぞれについて研究開発が進めら れている。

フラックス管理が完成した暁には、土砂フラッ クスの時空間分布が常に把握され、例えば、侵食 域が拡大する前の予防的な対策の実施、侵食が生 じた際に砂浜が自然のプロセスで回復する可能 性の診断等が可能になると考えられる。

以上に必要となる土砂フラックス把握の分解 能は、時間的には台風、冬季の暴浪等の荒天前後 の変化 (短期間)、年間に生じる季節的な変化 (中 期間)、数年から数十年にわたる変化トレンド (長 期間) であり、空間的には海岸構造物のスケール （オーダ : 百メートル）となる。また、多くの土 木事業が単年度の予算で実施されることを考え ると、土砂フラックスの推定・把握は即時的に行 えることが望ましい。ただし、残念ながら、前節 に説明したように、土砂フラックスの評価は難し いのが現状であり、これを打破する手法の提案が 望まれる。

\section{3. 河口域における土砂輸送量の推定に向けて}

ここでは筆者が行っている天竜川河口の X バ ンドレーダ観測の紹介をする。天竜川が注ぎ込む 遠州灘には侵食で苦慮している海岸地先が多く ある。天竜川は、河口より上流約 $30 \mathrm{~km}$ の地点よ り沖積地を形成し（天竜川平野、あるいは、遠州 平野)、これの沿岸部の一部が遠州灘である。こ の地域の海岸侵食の一つの要因として挙げられ るのが、天竜川の土砂供給減少である。この観点 より、多くの研究が行われ、近年では総合的に土 砂を管理し、流域から海域への土砂供給を増や寸 ためのダム再編事業が行われている。

筆者の行っている観測では、出水時に河川から 海域に運ばれる土砂量の推定を目指している。研 究の途中ではあるが、現時点の成果を紹介寸る。 

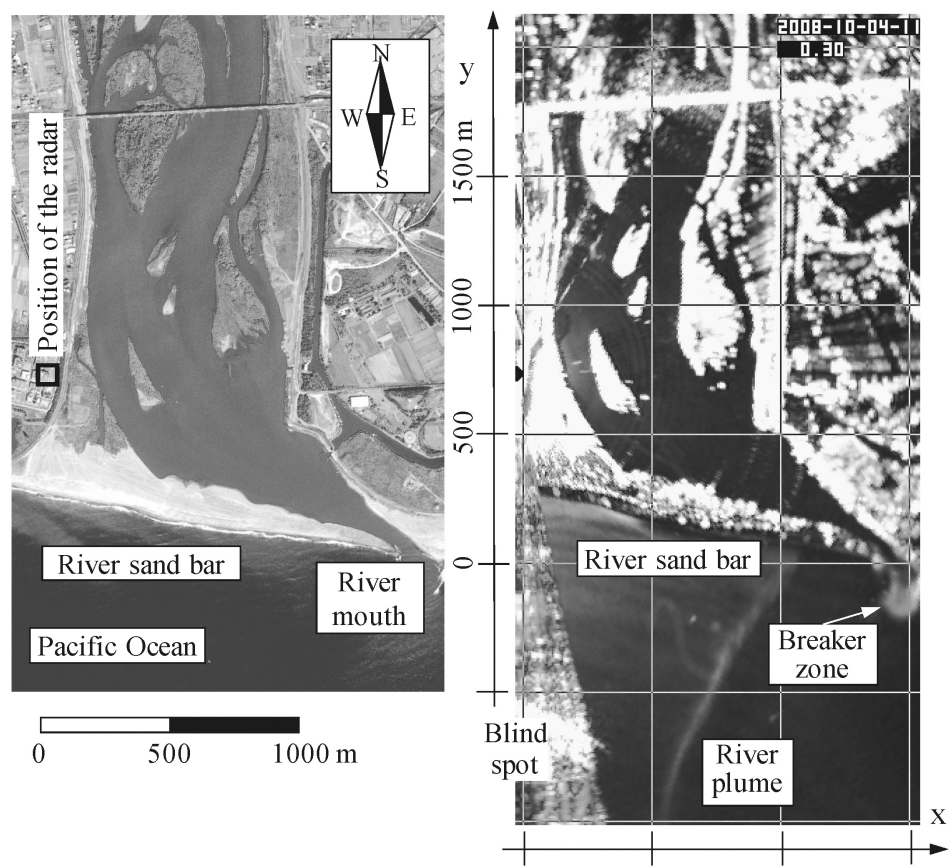

Fig. 4 Observation site at the river mouth of River Tenryu, Shizuoka, Japan. (Left panel) Satellite image of the study area. (Right panel) Time-averaged radar image, coordinate system. Satellite image: Ikonos-2. Acquisition date/time: October 4, 2008, 10:54 JST. Time-averaged radar image: average of images collected from 11:00 JST to 11:17 JST on October 4, 2008.
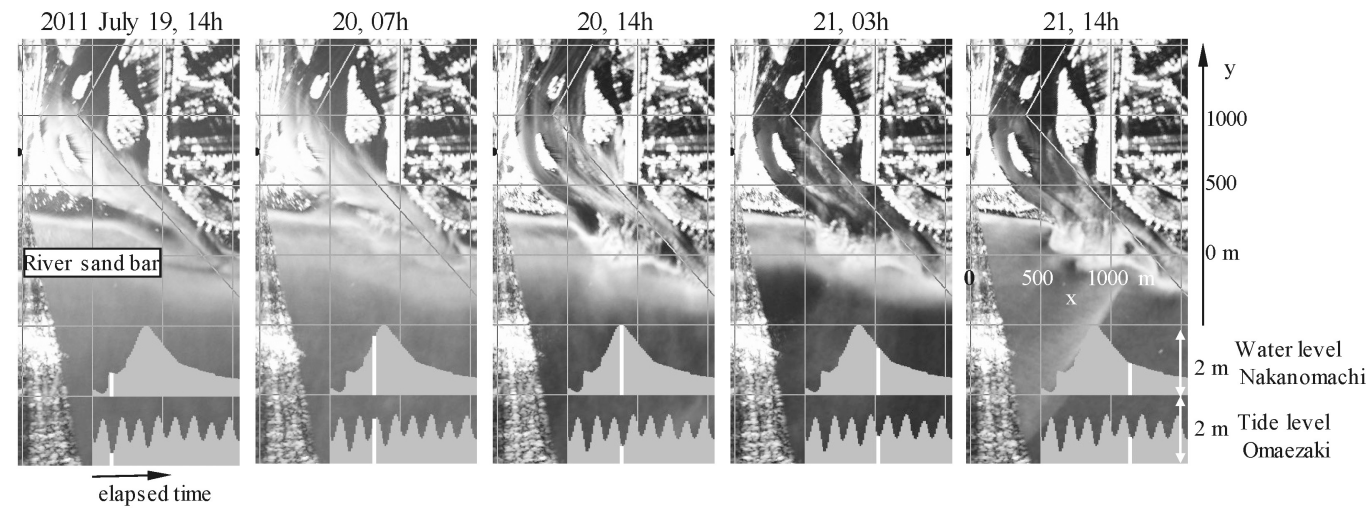

Fig. 5 Morphological processes during a flood in July 2011. Sequence of time-averaged radar images at different stages of the flood from July 9, 2011, $14 \mathrm{~h}$ to July 21, 2011, $14 \mathrm{~h}$ is displayed, which show as if the river flow is putting out sediment to the coastal area. The lower portion of each image shows the water level variations measured at the Nakanomachi station in the river, and the Omaezaki tide level station. The white vertical lines in the lower portion denote temporal positions in the radar acquisition. Movie of this sequence is uploaded on YouTube https://youtu.be/k5ALaVjc-aA.

\subsection{X バンドレーダによる沿岸域の観測 \\ X バンドレーダ (マリンレーダ) は船舶に搭載}

し、周辺の障害物を検知することを目的としてい る。この機器の本来の使途は船影、岩礁などの航
行の支障となるものをレーダ画像として捉える ことで、同時に映る水面からの情報（表面波）は 不必要なものである。海岸、海洋に携わる研究者 はレーダ観測の副産物として映る波浪に着目し、 


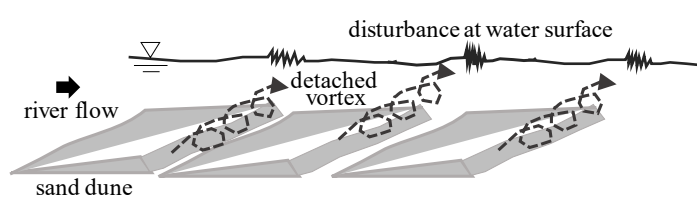

Fig. 6 Schematic explanation of imaging mechanism of bright-dark patterns in the time averaged radar images.

研究に応用することを検討してきた。Xバンドレ ーダは個々の波 (周期 10 秒のオーダ、波長 数 10 $\mathrm{m}$ から $100 \mathrm{~m}$ のオーダ) の伝播状況を捉え、数 $\mathrm{km}$ の範囲の広範な波浪場の時間的な変動を連続的 に捉えることが可能である。

著者はこのレーダを用い、汀線位置の測定、波 の伝播解析による海底地形の推定、汀線形状の年 間の変化等の海岸地形の観測に関する研究を進 めてきた。天竜川における観測もこの一環として 行われたものであり、出水時の観測結果より、河 川から海域に土砂が供給される過程を紹介寸る ([7 - 9])。

\section{2 天竜川河口域における観測}

$\mathrm{X}$ バンドレーダを天竜川河口右岸にある下水 処理施設の屋上に設置した。Fig. 4 に観測サイト、 座標系、レーダ画像を時間平均 (平均時間 : 約 17 分）した平均画像、対応する衛星画像などを示す。 座標系は東西方向に $x$ 軸、南北方向に $y$ 軸を設定 した。平均画像は解析に用いる部分を取り出して 表示してある。輝度值の大きい部分が陸域に対応 しており、河道内の砂州、河口、河口砂州の水際 位置、河川水フロントの発生などの状況を判読で きる。河口砂州の海側にある水際位置の一部はレ ーダ設置位置から見て死角領域となるために映 らず、また、下水処理施設内にある塔が妨げとな ってレーダェコーを取得できない領域が扇状に ある。

\section{3 出水時の観測結果}

河川上流域で降雨があると河川水位が上昇し、 出水が生じる。出水時には流れが早くなり土砂の 移動が活発になる。年に数回程度観られる規模の 比較的大きな出水があった 3 日間の平均画像を 分析すると、あたかも河川から海域に土砂が押し 出されるような画像が取得される (Fig. 5)。これ は河道にあった底面地形の凹凸（砂堆）が移動し たものの反映であると考えている。Fig. 6 に砂堆 上でレーダの反射の強弱（輝度パターン）が現れ
るメカニズムを示す。砂堆の背後に剥離渦が形成 され、これが離脱して水面に到達すると水面上の 乱れが増加してレーダの反射が増すと考えてい る。この出水時の観測結果 (動画) をYouTube に 掲載している (https://youtu.be/k5ALaVjc-aA)。

以上は、残念ながら土砂フラックスを直接観測 したものではない。流れが大きくなり土砂移動が 活発になり、その結果として生じた河床地形の時 間変動を間接的に観測したものと考えている。式 (1) で言えば第一項のみを捉えたもので、肝心の 土砂フラックスは何等かの方法で推定しなけれ ばならない。

この輝度パターンの下流方向への移動速さは、 出水のピーク時に増加し、また、海域と河川の間 の水位勾配が大きくなると増加するという特徵 がある。複数の出水時に観られた河道内のパター ンの移動速さと出水の規模（河川-海域間の水位 差）を比較したところ、両者に相関が見られた。 これより、輝度パターンの移動速さは土砂移動の 活発さを代表する量であり、これの下流方向への 移動状況の分析により、河川から海域に向けての 土砂移動の推定ができると考えた。

砂堆の出水中の挙動に関する報告によると、砂 の移動速さは $0.0001 \sim 0.001 \mathrm{~m} / \mathrm{s}$ のオーダにあ ること、河川流が増すと移動も大きくなることな どが観測結果として紹介されており、これらの特 徵はレーダ観測で得られた結果と整合する。これ より、レーダ観測結果に観られる輝度パターンの 移動は砂堆の移動を捉えたものとした。

河川工学では、砂堆の移動に関する分析が行わ れている。例えば、河床地形の移動速度と土砂フ ラックスの関係を求めた研究成果 (式 (1) と流砂 フラックスを連立させた式系の安定解析）があり、 ここに、観測で得られた輝度パターンの移動速さ を代入し土砂フラックスを算出した。測量により 求めた出水中の土砂フラックスを積算した量を 求めたところ、出水により河口域に堆積した土砂 量の数割分を説明できた。今後、この方法で河川 から河口域に供給される土砂量 (= 出水中の土砂 フラックスの積算值) をより正確に見積もるため には観測事例を増やし、また、数值計算を援用す ることが必要と考えている。

\section{4. むすび}

本稿では、海岸地形の変動と土砂フラックスの 
関係、これらの観測方法、海岸侵食対策について 簡単に説明した。続いて、筆者が取得した河川か ら海岸に運ばれる土砂量を推定するための観測 結果を示し、河川から海域への土砂フラックスを 推定する試みについて説明した。残念ながら、海 域、河口域における土砂フラックスの直接的な測 定結果、あるいは、尤もらしい推定結果を示すに は至らなかったが、この方面の研究の成果活用の 方向性と土砂フラックス推定の難しさを感じ取 って頂ければ幸いである。

\section{Nomenclature}

$h \quad$ : bottom elevation [m]

$Q_{x}, Q_{x}:$ sediment flux (per unit time and width)

$\left[\mathrm{m}^{3} / \mathrm{s} / \mathrm{m}\right]$

\section{参考文献}

[1] Horikawa, K., Coastal Engineering, University of Tokyo Press (1978).

[2] Goda, Y., Coastal Engineering, Gihodo Shuppan (2012).

[3] Horikawa, K. (Editor), Nearshore Dynamics and Coastal Processes -Theory, Measurement, and Predictive Models-, University of Tokyo Press
(1988).

[4] Kuriyama, Y., Beach Deformation, Gihodo Shuppan (2006).

[5] Takewaka, S., Measurements of Shoreline Positions and Intertidal Foreshore Slopes with Xband Marine Radar System, Coastal Engineering Journal, Vol. 47, 91-107 (2005).

[6] Hasan, G. M. J. and Takewaka, S., Observation of a Stormy Wave Field with X-band Radar and its Linear Aspect, Coastal Engineering Journal, Vol. 49, 149-171 (2007).

[7] Takewaka, S., Visibility of River Plume Fronts with an X-band Radar, Journal of Sensors, Article ID 6594847 (2016) (doi:10.1155/2016/6594847).

[8] Takewaka, S., Observation of Whole Flushing Process of a River Sand Bar by a Flood Using XBand Radar, Journal of Marine Science and Engineering (2016) (doi:10.3390/jmse4020032).

[9] Takewaka, S. and Ono, T., X-band Radar Observation of Morphological Changes due to Flood Events at the Mouth of Tenryu River, Japan, Coastal Engineering Journal, Vol. 60, 387-399 (2018) (doi:10.1080/21664250.2018.1529264). 